\title{
Marianne Gosztonyi Ainley \\ Creating Complicated Lives: Women and Science at English-Canadian Universities, 1880-1980
}

Marelene Rayner-Canham and Geoff Rayner-Canham, eds. Montreal: McGill-Queen's University Press, 2012. 200 pp.

\section{Michelle Hoffman}

University of Toronto

Creating Complicated Lives is the result of over two decades of archival research, scholarship, and interviews conducted by Marianne Gosztonyi Ainley. She began this work in her years as a doctoral student in the 1980s and continued until her retirement years in the early 2000s. This assiduously researched volume offers a mix of biography and autobiography as it surveys 100 years of Canadian women in science, focusing on women's roles, across the spectrum of pay and status, as students, professors, administrators, researchers, and technicians within English-Canadian universities.

The book is markedly personal in tone. The first chapter chronicles the author's own "journey to feminist enlightenment," (9) describing, among other episodes, her first career as a chemical technician and her subsequent graduate studies in history and sociology of science. In 1980, as a PhD student, she came across Margaret Rossiter's early work on the history of American women in science, an encounter that permanently reoriented her own research agenda. Ainley recounts her initial struggle to establish a sustainable research program on Canadian women scientists by chronicling her successive grant applications, some successful, but several dishearteningly rejected. Her account highlights her efforts to refine and articulate her research goals, as well as the broader challenges of breaking new ground in academia as an early-career researcher, when scholars are especially dependent on favourable funding decisions.

In the remaining four chapters, which span the period from 1880-1980, Ainley turns the lens onto the many women whose biographies she unearthed in her twenty years of research. Her narrative voice permeates these chapters as well, as she freely describes her own challenges, impressions, and discoveries as a researcher. Much like 
Rossiter, Ainley found that the initial challenges presented by the apparent paucity of archival sources on women scientists were eventually overtaken by the greater challenge of organizing the vast amounts of material she had accrued.

Chapters are organized along two main axes: chronological period and women's marital status. Marital status is significant here for two reasons. First, Ainley is careful not to impose any one universal model of women's careers, and she is particularly wary of past tendencies to draw excessively on the experience of married women professionals. Accordingly, she dedicates a chapter to the experience of single women scientists. For many women, marriage and employment were mutually exclusive life choices, particularly prior to the 1920s — though of course, stark trade-offs were assumed by many well beyond that.

Second, marital status is a significant demarcation criterion, not least because many Canadian universities employed hiring policies that were ostensibly designed to preclude nepotism, but in practice, prevented women scientists from being hired in the same departments as their husbands. Effectively, this meant that women scientists who had met and married their husbands as fellow students were often barred from permanent academic positions when their husbands secured professorships. Many of these academic wives were relegated to low-status, low-pay jobs such as laboratory demonstrators, technicians, or, when the need arose (such as in wartime), lecturers. Others opted to do unpaid work on their own research or as assistants their husbands, often sharing their office space. Ainley points out, however, that Canadian nepotism rules were sometimes flexible or even "fictitious": they could be summoned to exclude qualified women, but were sometimes also bent when it was expedient - for instance, "when it suited [administrators] to hire academic wives" (153). Ainley's interviews show that while some women chafed under these policies, many women simply accepted them, and few recalled perceiving their experience as sexist or unjust. As Ainley reminds us more than once, "As historians we have to be careful not to impose our contemporary perceptions onto the people whose lives we are interpreting. We may consider that the professional lives of many women stagnated . . . but their own perceptions of their work opportunities and options may have been quite different" (76).

These last four chapters consist primarily of approximately fifty short vignettes, usually one to two pages long, of Canadian women scientists whose biographies she unearthed in the course of her extensive research. Ainley's decision to use a biographical, qualitative approach flows out of her choice of analytical lens, namely, "life course change," which is defined as "a biographical/geographical approach that follows women's lives across space and time" $(6,91)$. One of her aims is to avoid comparing women's working lives to a "male-stream" career norm (53). As a result, Ainley casts a wide net in her research, making sure to include often overlooked roles, including "in/visible assistants" (127) such as laboratory technicians. She takes pains not to overgeneralize within her categories of analysis and repeatedly points to the variety of women's individual experiences, whether married, single, mothers, or childless. In framing her story, Ainley continually draws on a broad range of secondary literature, evincing a deep familiarity with feminist scholarship spanning the past four decades. 
Ainley passed away in 2008, when the book manuscript was in its second draft. The manuscript was edited by Marelene Rayner-Canham and Geoff Rayner-Canham, who were keen to preserve Ainley's voice while refining the narrative structure. In describing her purposes for the book, Ainley notes that a single volume "cannot ... do more than create interest in the subject and lead to further investigations" (43). This book has surely exceeded those goals. It offers a comprehensive treasury of valuable biographical information, accompanied by many analytical insights, for anyone interested in the history of women in science. Marianne Ainley planned to donate her research materials to the University of Victoria archives, and invited other researchers to continue her important work. 